\title{
The costs and benefits of nurse migration on families: A Lesotho experience
}

\author{
Authors: \\ Matsola E. Ntlale ${ }^{1}$ \\ Sinegugu E. Duma \\ Affiliations: \\ ${ }^{1}$ Division of Nursing and \\ Midwifery, University of \\ Cape Town, South Africa \\ Correspondence to: \\ Sinegugu Duma \\ Email: \\ Sinegugu.Duma@uct.ac.za \\ Postal address: \\ F45, Old Main Building, \\ Groote Schuur Hospital, \\ Observatory, 7295, \\ South Africa \\ Dates: \\ Received: 04 July 2011 \\ Accepted: 01 Dec. 2011 \\ Published: 22 Feb. 2012 \\ How to cite this article: \\ Ntlale, M.E \& Duma, S.E., \\ 2012, 'The costs and \\ benefits of nurse migration \\ on families: A Lesotho \\ experience', Curationis \\ 13(1), Art. 13, 8 pages. \\ http://dx.doi.org/10.4102/ \\ curationis.v34i1.13
}

(C) 2012. The Authors. Licensee: AOSIS OpenJournals. This work is licensed under the Creative Commons Attribution License.
The present day migration of nurses from developing countries, to more developed countries, depletes these countries of this vital human resource, which is necessary to provide optimum quality nursing care to their populations. If nurse migration persists, the health systems of these countries face collapse.

It is important that a nurse understands the costs and benefits of migration to their families, whom they leave behind. This is not only to curb the problems that may occur, but to help the migrant nurses to realise how migration affects their families, especially their children and spouses, before they decide to leave their home countries to work in foreign lands.

The purpose of this study, which was exploratory, descriptive and qualitative, was to investigate and describe the experiences of family members, of migrant nurses, from the Maseru district of Lesotho, about the costs and benefits of nurse migration. The objectives were to explore and describe the disadvantageous costs and the benefits gained by the families of migrant nurses. These were explored through the research question 'What are the experiences of family members of migrating nurses with regard to the costs and benefits of nurse migration?'

The target population of the study was families of migrant nurses from Lesotho. Using purposive sampling the families of two migrant nurses, who were colleagues of the researcher, were identified and approached to participate in the study. Snowball sampling was next utilised to recruit the remainder of the participants. In total, six families were identified and included in the study.

The semi-structured interviews and field notes were the two data collection methods that were implemented. The Giorgi's (1970) steps for data analysis, as outlined in (Burns \& Grove 2001:610), were followed and seven themes were discovered as findings. The themes that relate to the costs of nurse migration are: emotional instability, weaker family connections and increased responsibility. The themes that relate to the benefits of nurse migration for their families are: better household income, improved quality of life, essential skills development and travelling opportunities.

The use of communication technology is recommended to increase contact across borders in order to reduce the emotional costs of nurse migration on the families of migrant nurses. The article provides a balanced view of the costs and benefits of nurse migration on their families.

\section{Introduction}

\section{Background and literature review}

The migration of nurses from under developed countries depletes these countries of this vital human resource, which is necessary to provide optimum quality health or nursing care to their populations. Nurse migration contributes to under-staffing in the health care sector, which leads to poor health service delivery. If this trend persists, the health care systems of developing countries, like Lesotho, face collapse.

Nurse migration implies moving from one country to another in search of employment and better living conditions (Kingma 2001:205). This migration is an ongoing concern in developing countries and shows no signs of diminishing (Chikanda (i)2005:162). The factors that influence nurse migration are many. Some of the prominent factors are the nurses' ability to exercise their right to freedom of movement and better remuneration, globalisation, the advancement of and access to transportation networks and information technology, and internationally recognised qualifications. These factors all make it possible for these skilled health professionals to practice 
nursing anywhere in the world where they are valued (Ogilvie, Mill, Astle, Fanning \& Opera 2007:114; Chikanda (ii)2006:668; Buchan 2006:17).

The recruitment practices of high-income countries also attract migrant nurses from underdeveloped countries, especially sub-Saharan Africa, to meet their health-care demands. The availability of nursing jobs in these highincome countries exceed their domestic supply of nurses (Troy, Wyness \& McAuliffe 2007:1). This recruitment practice continues despite its denouncement by the International Council for Nurses (ICN 1999a:1-6).

The magnitude of nurse migration in Lesotho is extensive and may cripple the country's health system if not addressed. It has already resulted in the country's failure to implement the national campaign to prevent infectious diseases, due to understaffing (Medecins Sans Frontieres (MSF) 2007:11).

About 54\% of professional nursing posts in Lesotho's health centres are vacant. This situation is worsened by the continuous migration of nurses to well-developed countries. Between 2003 and 2004 at least 50 nurses from Lesotho were registered to work in the UK. (UK Nursing and Midwifery Council [2005], cited in Connel, Zurn, Stilwell, Awase, and Brainchet [2007:1881]). It was further reported that, at least, an additional 43 nurses and midwives from Lesotho left the country in 2004 and 2005 to work in other countries such as the USA, Saudi Arabia and other developed countries (Cobbe 2004:3; Baven 2005:1916).

It is also reported that in 2002 South Africa, a neighbouring country to Lesotho, lost $1 \%$ of its nursing workforce to the United Kingdom (Ross, Polsky \& Sochalski 2005:253). By 2006, this was reported to have reached 5.1\% (Clemens \& Petterson 2006) with the likelihood of South Africa offsetting this by recruiting nurses from its neighbouring poor countries such as Lesotho.

The trend of nurse migration is predicted to continue, until developed countries have addressed the cause of the nursing shortage in their own countries, and developing countries have managed to address the factors that force nurses to migrate to these countries (Kline 2003:107; Oosthuizen, Ehlers \& Jooste 2005:59; Buchan 2006:20-21).

\section{Problem Statement}

The escalating migration of nurses has attracted scholarly attention as a result of the detrimental effects this exerts on the provision of health services in developing countries. However the impact of nurse migration on family members, especially on spouses, extended family members and children, who are often left behind, has not been studied. The benefits and costs, that family members experience, are not known. It is unknown whether or not the benefits (positive effects) of migration (if any) outweigh the costs (negative effects) experienced by families.
A study, to investigate the experiences of family members of migrant nurses, in the context of the costs and benefits of nurse migration, was found to be imperative for Lesotho, which is a country that is currently scourged with nurse migration.

\section{Aims of the study}

Insight into the costs and benefits, of nurse migration, to the families who are left behind, is important. This insight is important, not only to help curb this phenomenon, but to help future migrant nurses to know how this is viewed by their families, especially children and intimate partners, before they decide to leave their countries for work in foreign lands.

The aim of this study was to explore and describe the experiences of the family members of migrant nurses from the Maseru district, Lesotho, with regard to the costs and benefits of nurse migration. This paper aims to contribute this specific focus to the overall concern about the phenomena of nurse migration.

\section{Background}

According to The World Health Organisation Report (2006), there were only 1123 professional nurses and midwives working in Lesotho, which indicated that the country was short of 700 professional nurses. As a result, the national campaign to implement confidential HIV testing and counselling services was postponed (Integrated Regional Information Network (IRIN) (2006) and Associated Press (2006) cited in Kingma (2007:1268)).

Poor remuneration, and the inability to save money quickly to achieve better living conditions, are reported as factors that force nurses to leave their home countries to work in foreign countries (Kingma 2001:206) Poor infrastructure, poor working conditions and being devalued are also reported among the push factors for nurse migration. (Awases, Gbary \& Chatora (2003) cited in Thupayagale (2007:107); Denton (2006:77) and Kline (2003:107)).

The nurses' concern for personal safety from occupational infection, from HIV or AIDS, and Tuberculosis, is another significant push factor. It has been argued that the high prevalence of HIV and AIDS in developing countries is a contributing factor, because nurses are continually exposed to infection, without access to adequate protective measures (Kline 2003:108; Thupayagale 2007:107).

\section{Research objectives}

In view of the above concerns, the objectives of the study were to explore and describe the costs and the benefits associated with nurse migration as experienced by their families. These were explored through the research question 'What are the experiences of family members of migrating nurses with regard to the costs and benefits of nurse migration?' 


\section{Definition of key concepts}

For the purpose of the study the researcher incorporated the following key concepts:

- Costs may be financial, social and emotional losses. These contribute to the negative effects of migration, as experienced by the families of migrant nurses from Lesotho.

- Benefits are the monetary gains, and any positive social or emotional effects derived from this gain, by the family members of migrant nurses.

- A family refers to the migrant nurses' close and extended relatives, including their intimate partner or spouse, children, parents, siblings and other extended family members. This is an African perspective of the family (Starbuck 2002:2-10).

- Migration is the movement of nurses from their country of birth to other countries, especially developed countries, for employment and possibly other incentives.

\section{Contribution to the field}

Despite the extensive literature written on the push and pull factors of nurse migration, there is a remarkable paucity of research literature addressing the experiences of the family members of migrant nurses. This makes it difficult, for the migrant nurses to understand the experiences of their families, concerning the costs and benefits of migration.

\section{Research methods and design Design}

A qualitative, explorative and descriptive approach was followed as a research design for the study. This approach was considered appropriate to understand the underlying meaning of the experiences of families of migrant nurses, with regard to costs and benefits.

\section{Population and sample}

The target population of the study consisted of the family members of nurses who had left Lesotho to work in other countries for a period of more than two years. Both purposive and snowball sampling methods were implemented to select the study's participants. Purposive sampling involves choosing candidates, to participate in the study, who are knowledgeable about the phenomenon being studied (Brink 2003:141). This sampling technique is based on the researcher's knowledge of participants who qualify for the study, and who can provide the required information (De Vos 1998:198). Snowball sampling, which is also known as network sampling, is based on the premise that people with similar characteristics know each other. The researcher identifies key informants, who will assist her or him to find other participants (Burns \& Grove 2001:376). The earlier informants are asked to identify and refer other people for the study, who meet the eligibility criteria (Polit \& Hungler 1994:177).

Using purposive sampling, the families of two migrant nurses, who were colleagues of the researcher, were identified and approached to participate in the pilot study. These were regarded as the primary informants for the study. During the first visit the primary informants were asked to suggest other families, of migrant nurses, to participant in the study. Thereafter the researcher contacted the suggested informants and recruited them to participate in the study. These families were then each asked to identify other families of migrant nurses. In total, six families were identified and included in the study.

The family members who participated included the following: Three spouses, four children, two siblings (younger sisters) and one parent (mother) of migrant nurses. The sample therefore consisted of a total of ten participants, who were individually interviewed.

\section{Data collection methods}

Data was collected between February and July 2007, using structured interviews and field notes as data collection methods. Data collection was stopped when data saturation was reached. The interview guide consisted of two main questions and additional probing questions. The main questions were: 'Can you tell me about the good things you have experienced or benefited from him or her being away?' and 'Can you tell me about the bad things you have experienced in his or her absence?' These were followed by probing questions that were chosen on the basis of the participants' response to the two main questions.

The interviews were held in each participant's home, which was regarded as a natural environment for the interviews to take place (Struebert \& Carpenter 1999:16; Neuman 1997:349). The interviews were conducted in Sesotho and were audiotaped. The data were transcribed verbatim within twenty four hours of the interview to ensure accurate recording of the participant's data, as recommended by Duma (2006:113). The transcribed data were translated into English by a qualified and experienced Sesotho-English translator. The English transcripts were read and verified by the researcher to avoid possible loss of meaning. A colleague who understands both English and Sesotho also read and verified both the Sesotho and English transcripts.

\section{Pilot study}

Two families of migrant nurses, who were known to the researcher, were identified and approached for the pilot study. The purpose of the study was explained according to the study protocol. Two members from each of these families were interviewed. Data obtained from these interviews were analysed in the main study, because the collection methods implemented and questions asked during the pilot study and the main study were the same. This is supported by Duma (2006:90), who states that pilot study data does not contaminate the main study and should be included as part of it.

\section{Data analysis}

The Giorgi's (1970) steps of data analysis, as outlined in Burns \& Grove (2001:610), were followed. These include reading 
the entire set of data or descriptions to develop a sense of the whole collection of data; re-reading the whole set of data to discover the essence of the phenomenon under study; and expressing the psychological insight contained in each of the meaning units more directly. The end result of this exercise was the formulation of a series of meaning units. The determined meaning units were examined for redundancies, clarification or elaboration by relating their meaning to each other. This was followed by reflection on the meaning units and systematic interrogation of each meaning unit. The units were then transformed into a consistent statement regarding each participant's response to the phenomenon under study. The researcher synthesised and integrated the insight obtained in the above steps, and from it identified the seven themes as findings of the study. These are discussed in Table 1 and Table 2.

\section{Context of the study}

The study was conducted in the Maseru district, which is the capital city of Lesotho. Maseru lies in the west of the country, in the lowlands. There are three public hospitals and one private hospital within this district. The migrant nurses' family members were selected within the catchment areas of these hospitals.

\section{Results}

The findings are organised as follows:

Table 1 addresses the themes, meaning units and examples of abstracts, taken from collected data, on the costs of nurse migration to their families. Table 2 addresses the same criteria as Table 1, but on the benefits of nurse migration to their families.

TABLE 1: The meaning related to costs of nurse migration to their families.

\begin{tabular}{|c|c|c|}
\hline Theme & Meaning Units from data & Examples of abstracts from data \\
\hline & $\begin{array}{l}\text { Missing the migrant } \\
\text { nurse, unhappiness in } \\
\text { his or her absence, } \\
\text { constant worrying } \\
\text { about the well-being } \\
\text { of the nurse. }\end{array}$ & $\begin{array}{l}\text { 'I miss her, we miss her because she is not with you ... yah ... we really miss her ... she is always on my mind ... she normally comes } \\
\text { home after six months and spends one month or less with us ... when we get used to her she goes away again.' } \\
\text {.... what is left is that we are human beings ... as human beings ... we miss each other ... yes, I miss her as my wife ... that is the } \\
\text { issue.' } \\
\text { 'There is no joy in the family ... especially when a member of such a family is that far ... and then he comes home after a long time } \\
\ldots . . \text { I am sure you understand how ... that is ... many things are happening here and even for myself as his wife [frown] ... really it } \\
\text { is hard for me.' } \\
\text { 'If there is an event or occasion at school ... like parents' meetings, 'open days' and cultural events, if I don't go with her ... I feel } \\
\text { unhappy ... because you will find that other children go with their parents ... and I don't go with my real parent.' } \\
\text { 'Last time before she came here ... she told us that she is sick and we were scared ... thinking that her illness is serious ... I become } \\
\text { worried if she says she is sick.' } \\
\text { 'We end up being suspicious which I think is normal when you are not together ... when one is far away you end up asking yourself } \\
\ldots \text { what is he doing there when I am alone here ... may-be he is with somebody ... all useless things ... when he comes home after } \\
\text { some time ... you think he has changed.' }\end{array}$ \\
\hline & $\begin{array}{l}\text { Socialising together, } \\
\text { problem solving and } \\
\text { family insecurity }\end{array}$ & $\begin{array}{l}\text { 'We are unable to attend funerals with her ... you will find that somebody ... let me say a distant relative has passed away ... we } \\
\text { need her company in such situations.' } \\
\text { 'It is not nice ... not to be with her under certain situations ... and sometimes we need to be with her on special events such as } \\
\text { wedding ceremonies ... I always wish to be with her.' } \\
\text { 'We used to attend morning mass together as a family ... now that he is not here I go to church with my daughter and I have } \\
\text { joined a church choir ... because he is not here.' } \\
\text { 'Sometimes I have a feeling that ... she could be around so that we can tackle problems together ... and that she might be in a } \\
\text { position to help me to solve some of my problems ... if she is around.' } \\
\text { 'I feel frustrated at times ... I need a partner whom I can talk to ... or whom I can share my problems with ... or we can do things } \\
\text { together ... and support me ... his absence means I need to be on my own ... which is sometimes difficult in-deed.' } \\
\text { 'As a child you go to school and sometimes you did not grasp what the teacher said in class ... and you go home ... hoping that } \\
\text { your parents will help you to come up with a solution to the problem.' } \\
\text { 'This stresses me if I need to talk to someone who can assist me ... and whom I can share my problems with.' } \\
\text { 'We are not safe in his absence ... sometimes I am scared that people might attack us ... knowing that my dad is not around.' } \\
\text { 'Currently we are not safe in our homes because of theft ... I wish he was around ... because his presence means we are protected } \\
\text {... and that keeps us comfortable.' } \\
\text { 'Sometimes I feel unsafe in his absence ... you know nowadays people are attacked ... sometimes I wake up at night ... frightened } \\
\text {... as if somebody was in the house ... to attack us.' } \\
\text { 'You know ... family security is very weak ... we need a male figure in the house for our protection ... we can even sleep without } \\
\text { locking the doors llaughing].' }\end{array}$ \\
\hline $\begin{array}{l}\text { Expanded } \\
\text { responsibility }\end{array}$ & $\begin{array}{l}\text { Attending to other } \\
\text { people's affairs, and } \\
\text { decision making }\end{array}$ & $\begin{array}{l}\text { 'I have my personal affairs ... and on top of that I have to attend to my sister's affairs (migrant nurse's affairs). I feel frustrated but } \\
\text { I always tell myself that I will do everything because I am the only one she has relied on.' } \\
\text { 'I have to do other tasks that are not my entire responsibility which I am not used to ... I am doing everything, everything.' } \\
\text { 'I need to do all of them ... of course they are heavy ... sometimes I could feel that I am under pressure ... they need her as the } \\
\text { owner of the house.' } \\
\text { 'You will find that I have to make many decisions on everything because he is away ... he only agrees. Maybe if he was around he } \\
\text { would have come up with something else ... He only agrees to decisions that I make without knowing exactly what is happening.' } \\
\text { 'Sometimes I feel like he could be here for quick decisions ... you see? And to help me with some of the decisions.' } \\
\text { 'What bothers me is that sometimes I need to make tough decisions... and before making such decisions I always have this feeling } \\
\text { 'this is not my house' ... so every move that I make I have to be very careful.' }\end{array}$ \\
\hline
\end{tabular}


TABLE 2: The meanings related to the benefits of nurse migration.

\begin{tabular}{|c|c|c|}
\hline Theme & Meaning Units from data & Examples of abstracts from data \\
\hline $\begin{array}{l}\text { Better household } \\
\text { income }\end{array}$ & $\begin{array}{l}\text { monetary gains, financial } \\
\text { assistance and } \\
\text { satisfaction of family } \\
\text { needs }\end{array}$ & $\begin{array}{l}\text { 'I can see that the money we are getting from him is different to what we used to get in the past ... he is giving me better money.' } \\
\text { 'I am getting more money from him.' } \\
\text { 'Since she left ... there are quite a number of improvements in our home ... which you will find that ... because of the exchange of } \\
\text { Pounds into Maloti [which is equivalent to the South African Rand] ... the money has more value for us ... because our currency } \\
\text { is lower as compared to the British Pounds.' } \\
\text { 'As you can see I am old and sick ... she is able to give me more money to attend my medical check ups ... to buy food and meet } \\
\text { other basic needs.' }\end{array}$ \\
\hline & $\begin{array}{l}\text { fixed assets, getting } \\
\text { quality materials and } \\
\text { better education for } \\
\text { children }\end{array}$ & $\begin{array}{l}\text { 'She has managed to acquire a site without anybody's help ... and she built this house ... we are now enjoying to stay in a new } \\
\text { house, well furnished.' } \\
\text { 'Mmm ... we did not have a water system in this house but since she left ... we were able to install a water system ... that is the } \\
\text { main thing that we have achieved ... or she has managed to do for us here.' } \\
\text { 'I think another good thing is that we managed to renovate this house ... we are now living in a bigger and well-ventilated house } \\
\ldots \text { unlike in the past when we were living in a small three-roomed house but now we are comfortable in a bigger house.' } \\
\text { 'When he comes home he brings us things from abroad [laughing] ... especially clothes ... [Laughing] ... especially clothes, cell } \\
\text { phones and he has bought me a big screen TV [laughing] the latest models ... well, these are the things which I have benefited } \\
\text { from him working abroad ... he also brought us shoes... expensive shoes ... quality labels [Laughing] and this makes us feel proud } \\
\text { and happy... I feel proud ... as I know that I am the first person to have this type of shoes in my community or in the country.' } \\
\text { 'We are getting better clothes and shoes from abroad ... clothes which are sometimes not available here ... or are available at } \\
\text { high prices... depending on the salaries that we get here... we are unable to buy them ... and these are not common clothes that } \\
\text { everybody can have.' } \\
\text { 'We are able to look for better schools for our children ... we compare schools and select the best school for our child ... now we } \\
\text { are able to compare schools ... you see? ... select the best school where our child can get a good education.' } \\
\text { 'We are able to pay for his tuition and accommodation fees... I can pay everything that is needed for his studies... she has helped } \\
\text { me a lot ... that gives me hope that our child will have a better education.' } \\
\text { 'Unlike other children ... I am enjoying my studies because she is able to pay for my tuition and accommodation fees, I am not } \\
\text { worried about unpaid university fees.' }\end{array}$ \\
\hline $\begin{array}{l}\text { Essential skills } \\
\text { development }\end{array}$ & $\begin{array}{l}\text { All the new skills that } \\
\text { family members had } \\
\text { to learn in the absence } \\
\text { of the migrant nurse, } \\
\text { including child-rearing, } \\
\text { being responsible and } \\
\text { independence. }\end{array}$ & $\begin{array}{l}\text { 'Having to look after her children before having my own child was important to me ... I became mom and dad for her children ... } \\
\text { this has taught me how to handle children.' } \\
\text { 'Having to stay with her children ... I take this as a huge responsibility and I have developed new skills in caring for children ... to } \\
\text { tell the truth I have learnt a lot.' } \\
\text { 'I have become more responsible ... and I am in charge of everything in the house.' }\end{array}$ \\
\hline
\end{tabular}

Source: Author's original data

\section{Ethical considerations}

The researcher adhered to the ethical principles of conducting research according to the Declaration of Helsinki (Polit \& Hungler 1994:360) which is as follows:

- Adult participants signed informed consent and were given a study information sheet in their own language for their own record.

- Children completed the assent form to show their willingness to be interviewed.

- Parents or guardians completed an additional informed consent for children, when agreeing that children should be interviewed.

- Permissions to conduct the study were obtained from a University of Cape Town Faculty of Health Sciences Research Ethics Committee, and the Director General of Health Services in Lesotho.

- Each participant was interviewed privately and their data was not shared with other members of the family.

- Data from participants shall be kept for a period of 5 years, as determined by the above university ethics committee.

\section{Trustworthiness}

The following measures, to ensure trustworthiness, were adopted throughout the study: credibility, dependability, and conformability. For credibility a triangulation of sources, a member check and a peer examination were applied. Triangulation involves the collection of the same data from multiple sources to verify the trustworthiness of the data (Polit et al. 2001:313). Data from interviews and field notes were analysed and interpreted together. The member check involves asking informants to comment on the collected data and the analysed data. Member checking was conducted informally, immediately after data collection (Polit et al. 2001:314). It was then later repeated formally, after data analysis was completed. In the formal member check, the participants were asked to comment on the analysed data. Raw data and analysed data (themes) were shared with the research supervisor who is an experienced qualitative researcher (and corresponding author), for validation of the findings and peer examination. According to Brink (2003:124), in peer examination, the researcher allows her or his peers to review and explore various aspects of the 
researcher's enquiry. The researcher was asked questions about the enquiry and was given expert guidance on data analysis and its interpretation, from her supervisor. This measure also ensured dependability of findings. An external reviewer, who is also an experienced qualitative researcher, was requested to review the raw data and analysed themes. She confirmed the interpretation of the meaning units and the relevance of the data. This ensured confirmability.

\section{Discussions}

The findings of the current study provide insight into the costs and benefits of nurse migration to the families left behind. They also revealed that the benefits to the family members, of the migrant nurses, far outweighed the costs. The benefits include financial and material gains, improved quality of life, and the development of essential skills (which would not have been developed if the migrant nurse had not left their family behind), as well as travelling opportunities for family members visiting the migrant nurses.

\section{Outline of the results}

The adverse consequences of nurse migration include missing the migrant nurse, unhappiness, lack of intimacy, potential fear of sexual promiscuity, and feeling overburdened with household chores. The current study revealed that families of migrant nurses are unhappy in the absence of the migrant nurses. The distance which separates the migrant nurses and their family members has contributed to the familys' unhappiness, as a result of the familys' inability to engage in family activities and cultural events together. In addition, it was discovered that the families are unhappy that they are not able to attend certain events or functions with the migrant nurses.

The emotional tie between the migrant nurses and their family members is negatively affected by the distance that separates them (Murray \& Zentner 1989:179). This was also reported by Carballo and Mboup (2005:5), who discovered that the family members who are left behind are prone to emotional dissatisfaction in the absence of the migrant workers. They also reported that the psychological and emotional distance that separates migrant workers from their loved ones, is psychologically eroding for everyone involved in the migration process, for both the migrant nurses and their families left behind. This can leave emotional scars on all of them (Kingma 2001:208). This emotional damage was additionally reported by the Episcopal Commission for the Pastoral Care of Migrant and Itinerant People-CBCP/ Apostleship of Sea-Manila, and Overseas Workers Welfare Administration (2003:38).

To keep the families that are left behind happy, Parrenas (2005:323) advises that the migrant nurses should nurture their families from a distance, and communicate with them across the borders as often as possible. This can be enhanced with the use of new technology such as cellular phones and Short Messaging Services (SMS), internet emailing and Facebook facilities, for those who can afford these technologies. Murray and Zentner (1989:108) also reported that the ease of communication over distance allows families to draw closer to each other emotionally. This was also a finding in the current study.

The potential sexual promiscuity among intimate partners is a reality that was reported by the marital spouses of the migrant nurses. Literature revealed similar findings among migrant workers who engage in risky sexual practices, due to loneliness, isolation and the decline in social and family control. This has dangerous consequences, such as being infected with STIs and HIV and AIIDS and could lead to death or divorce (Magis-Rodriquez et al. 2004:215; Cabada, Maldonado, Bauer, Verdonck, Seas \& Gotuzzo 2007:151; Brummer 2002:16). This problem was reported to far outweigh all benefits that nurse migration can give to families, especially their intimate partners or spouses.

According to Basotho culture, families ought to be together during funeral services and other cultural activities related to mourning for the deceased relative. It is regarded as essential for families to mourn or celebrate together, and to provide social and emotional support for each other during hard times. The absence of one family member may hinder the performance of some rituals within the family, especially during and following the death of a relative. According to Stockdale (2007: 60) this can be very dangerous, as social and family networks are important to determine one's choice of destination and in comforting each other in difficult times.

In Basotho culture a man is regarded as the protector of his wife, children and extended family. The families left behind are exposed to various social hazards in the absence of the migrant male nurses, including armed robbery, theft and other criminal acts. According to Blerk and Ansell (2006:259), livestock theft and house-breaking are common criminal activities in Lesotho. These researchers reveal that $57 \%$ of people living in Maseru, the capital city of Lesotho, feel unsafe in their homes, especially at night. This has contributed to a degree of fear, tension and mistrust among households and the community at large. This fear is more prevalent amongst the families of migrant male nurses. Male nurses who are also the heads of their families, need to take account of this circumstance when deciding to leave their families to work in foreign lands.

The most important benefit reported by the family members is financial gain. Similar findings were reported by Troy, et al. (2007:3) as well as Kingma (2007:1291), who showed that the effects of the migration of nurses are beneficial to their families and also to their home countries, through contributions to the welfare of their family members and to the national economy of their country of birth. Additionally, Ehlers, Oosthuizen, Buizedenhout, Monareng and Jooste (2003:24-57) reported that nurses migrate to earn better remuneration and to save money quickly, in order to cater for their own needs and the needs of their families. Baldassar 
(2007:390) also reported financial support as the key source of assistance to the families of the migrant workers. This is also consistent with the findings of Kingma (2001:206) who reasoned that the migration of nurses was based on improving the socio-economic opportunities of their families. In addition, Marilyn, Lorenzo, Galvez-Tan, Icamina and Javier (2007:1413) reported that nurses cite higher income, improved benefits and better compensation packages as the driving factors for migration. Improving the quality of life, such as 'getting better education for children', was also reported to motivate nurses to leave their native country and seek employment in First World countries (Kline 2003:107; The Episcopal Commission for the Pastoral Care of Migrant and Itinerant People-CBCP / Apostleship of Sea-Manila, and Overseas Workers Welfare Administration 2003:41)

The families of the migrant nurses benefit from the opportunities to travel abroad and see other parts of the world. This was also reported by Marilyn et al. (2007:1412) and Moran, Narrow and Butler (2005:5), who explained that motivation to work in the UK is intensified by the opportunity to travel, and to extend the career opportunities for migrant nurses. This thus allows the children of the migrant nurses to travel, learn about cultural diversity and the histories of other nations.

\section{Practical implications}

The findings of the study increase the consideration for nurses intending to leave their families behind and work in foreign lands. The issue of sexual promiscuity cannot be ignored because it has been reported to occur with migrant workers. Male nurses, who are also heads of their families, should consider the costs of their migration to their spouses and extended families. Children are most adversely affected by nurse migration, especially in cases of the migrant nurse being a single parent. Children may be left to be raised by people who hold different values to those of the parent. This should be considered when making plans to migrate. An alternative to this would be to negotiate for contracts that accommodate children and spouses, who can then join the migrant nurse.

\section{Limitations of the study}

The researcher could not return to participants for member checking after data analysis, due to pressures from coursework and the distance between Lesotho and the University. Only informal member checking was implemented at the completion of each interview. The mailing or postal services to Lesotho were considered to be unreliable, based on the researcher's previous experience. The participants therefore did not have the opportunity to comment on analysed data and the findings of the study. However, this did not affect the trustworthiness of the findings of the study because the research supervisor, who is an expert in qualitative data, interrogated the meaning and interpretation of analysed data and found findings to be scientifically sound.

\section{Recommendations}

In the light of the findings of this study, the following recommendations are made:

- Nurses who are in the process of migrating need to be made aware of the adverse consequences of migration on the families whom they will leave behind. This will allow them to make an informed decision prior to migration.

- There is a need for regular communication between the migrant nurses and their families left behind, and for the migrant nurses to provide emotional support and care for their families. If necessary, the family members must be equipped with and taught the use of electronic communication technologies, in order to encourage international communication between families and the distant migrant relative.

- The recruitment agencies should provide employment packages that allow nurses, in the process of migrating, to do so with their families, especially children.

- The Ministry of Health in Lesotho should ensure that community services are increased to cater for the needs of families of migrant nurses.

- The Ministries of Health in developing countries should review nurses' salaries and working conditions to retain nursing professionals in their countries.

- Future research on the migration of nurses is needed in Lesotho to ascertain the experiences of the migrant nurses, with regard to the benefits and costs of migration to themselves, and their experiences of working in a foreign country.

- There is a need for quantitative study which can investigate the impact of remittances on the economy of the country, that is, whether the country is benefiting from the migration of nurses or not.

\section{Conclusion}

There are always two sides to the same coin. Nurses who are considering migration should be able to consider both sides i.e. the costs as well as the benefits to their families. The use of available technology is recommended to enhance communication between countries in order to reduce some of the emotional costs of nurse migration to families. It is hoped that this article brings a balanced view about the costs and benefits of nurse migration to the families of migrant nurses, and contributes to the body of knowledge on the area of nurse migration.

\section{Acknowledgements}

The Lesotho Ministry of Health for study leave and university fees which afforded the researcher to complete this study.

\section{Competing Interests}

The authors declare that they have no financial or personal relationships which may have inappropriately influenced them in writing this paper. 


\section{Authors' contributions}

S.D. (University of Cape Town) was the supervisor of the research project from conceptualisation to completion of the study. She wrote the manuscript and implemented all corrections and revisions. E.M.N. (University of Cape Town) was the Masters degree student who conceptualised and conducted the study under supervision. However she was not involved in the actual writing of the manuscript. She returned to Lesotho in 2009 and could not be traced before the submission of the manuscript.

\section{References}

Baldassar, L., 2007, 'Transnational Families and the provision of moral and emotional support: The relationship between truth and distance', Identities 14 (4), 385-409, viewed 22 November 2007, from http://dx.doi.org/10.1080/10702890701578423.

Baven, S. 2005, 'Britain accused of ignoring Nurse-recruitment ban', The Lancet 366 (9501), 1915-1916. http://dx.doi.org/10.1016/S0140-6736(05)67772-0.

Blerk, L.V. \& Ansel, N., 2006, Imagining Migration: Placing children's understanding of 'moving house' in Malawi and Lesotho', Elsevier 37, 256-272.

Brink, H., 2003, Research Methodology for Healthcare Professionals, Juta \& Co. Ltd Cape Town

Brummer, D., 2002, Labour Migration and HIV/AIDS in Southern Africa, International Organizational of Migration Report, Regional Office for Southern Africa, Pretoria, South Africa.

Buchan, J., 2006, 'The Impact of Global Nursing Migration on Health service Delivery', Policy, Politics, \& Nursing Practice 7 (3), 16-25, viewed 03 march 2007, from http://ppn.sagepub.com/cgi/content/abstract/7/3_supl/16s

Burns, N. \& Grove, S.K., 2001, The Practice of Nursing Research, W. B. Saunders Company, Philadelphia.

Cabada, M.M., Maldonado, F., Bauer, I., Verdonck, K., seas, C., \& Gotuzzo., 2007. Sexual behaviour, knowledge of STI prevention, and prevalence of serum markers for STI among tour guides in Cuzco, Peru, Journal of Traveli Medicine 14 (3), 151- 7 .

Carballo, M. \& Mboup, M., 2005, International migration and health, A paper prepared for the Policy Analysis and Research Programme of the Global Commission on International Migration, viewed 12 December 2007, from http://www.gcim.org/ attachements/TP13.pdf

Chikanda, A., 2005, 'Nurse Migration from Zimbabwe: analysis of recent trends and impacts', Nursing Inquiry 12(3), 162-174. http://dx.doi.org/10.1111/j.1440 1800.2005.00273.x, PMid:16083467

Chikanda, A., 2006, 'Skilled Health Professionals' Migration and its impact on the Health Delivery in Zimbabwe', Journal of Ethnic and Migration Studies 32(4), 667-680. http://dx.doi.org/10.1080/13691830600610064

Clemens, M. \& Petterson, G., 2006, A New Database of Health professional Emigration from Africa, Centre for Global Development, USA.

Cobbe, J., 2004, Lesotho: Will Enclave Empty?, viewed 04 March 2007, viewed 3 March 2007, from http://www.migrationinformation.org/Profile/display.cfm?ID=248

Connel, C., Zurn, P., Stilwell, B., Awases, M. \& Braichet, J., 2007, 'Sub-Saharan Africa, Beyond the health worker migration crisis?' Social science \& Medicine 64 1876-1891. http://dx.doi.org/10.1016/j.socscimed.2006.12.013

De Vos, A.S., 1998, Research at Grass Root, Van Schaik Publishers, Pretoria.

Duma, S.E., 2006, Women's Journey from Sexual Assault to Recovery, University of Cape Town, Cape Town.

Ehlers, V.J., Oosthuizen, M.J., Bezuidenhout, M.C., Monareng, L.V. \& Jooste, K., 2003, 'Post-Basic Nursing Students' Perception of the emigration of Nurses from the Republic of South Africa', Health SA Gesondheid 8(4), 24-37.
Episcopal Commission For The Pastoral Care Of Migrant And Itinerant People-CBCP/ Apostleship Of Sea-Manila, Scalabrini Migration Center (SMC) And Overseas Workers Welfare Administration, 2003, Filipino Families in Motion, viewed 12 November 2007, from http://www.smc.org.ph/heartsapert/pdfs/Hearts\%20 Apart.pdf

International Council of Nurses, 1999a, Ethical nurse recruitment, Position statement, Geneva, viewed 17 March 2007, from http://www.icn.ch/psrecruit01.htm

Kingma, M., 2001, 'Nursing Migration: Global Treasure Hunt or Disaster in-theMaking?', Nursing Inquiry 8(4), 205-212. http://dx.doi.org/10.1046/j.14401800.2001.00116.x, PMid:11844042

Kingma, M., 2007, 'Nurses on the move: A Global Overview', Health Research \& Education Trust 14(3), 1281-1298.

Kline, D., 2003, 'Push and Pull Factors in international nurse Migration', Journal of Nursing Scholarship 35(2), 107-111. http://dx.doi.org/10.1111/j.15475069.2003.00107.x, PMid:12854289

Magis-Rodriquez, C., Cayet, C., Negroni, M., Leyva, R., Bravo-Garcia, E., Uribe, P. \& Bronfman, M., 2004, 'Migration and AIDS in Mexico: An Overview Based on Recent Evidence', Journal of Acquired Immune Deficiency Syndrome 37, suppl. $4(1)$, pp. s215-226.

Marilyn, F., Lorenzo, E., Galvez-Tan, J., Icamina, K. \& Javier, L., 2007, 'Nurse Migration from a source Country Perspective: Philippines Country Case Study', Health Source Research and education Trust 42(3), 1406-1418.

Medecins Sans Frontieres, 2007, Confronting health Care Workers Crisis to expand access to HIV/AIDS treatment: MSF experience in Africa, A testing challenge: The experience of Lesotho's universal HIVcouseling and testing campaign, Human Rights Watch, New York, USA

Moran, A., Narrow, S. \& Butter, A., 2005, 'There is no place like home': A pilot study of perspectives of international health and social care professionals working in the U.K', BioMed central 2, 2-25.

Murray, R.B. \& Zentner, J.P. 1989, Nursing Assessment \& Health Promotion Strategies through the Life Span, Appleton \& Lange, California.

Neumann, W.L. , 1997, Social research methods: Qualitative and quantitative approaches, Allyn \& Bacon, Boston.

Ogilvie, L., Mill, E., Astle, B., Fanning, A. \& Opare, M., 2007, 'The exodus of health

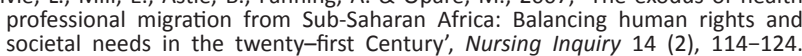
societal needs in the twenty-first Century', Nursing Inquiry 14 (2),
http://dx.doi.org/10.1111/j.1440-1800.2007.00358.x, PMid:17518823

Oosthuizen, M.J., Ehlers, V.J. \& Jooste, K., 2005, 'The Role played by Recruitment Agencies in the Emigration of South African Nurses', Health SA Gesondheid 10(3) Agencies

Parrenas, R., 2005, 'Long distance intimacy: class, gender, and intergenerational relations between mothers and children in Filipino transnational families', Global Networks 5(4), 317-336. http://dx.doi.org/10.1111/j.1471-0374.2005.00122.x

Polit, D.F. \& Hungler, B.P., 1994, Essentials of Nursing Research: Methods, appraisal and Utilization, J.B. Lippinocott Company, Philadelphia.

Polit, D.F. Beck, C,t, \& Hungler, B.P., 2001, Essentials of Nursing Research: Methods, appraisal and Utilization, J.B. Lippinocott Company, Philadelphia.

Ross, S.T., Polsky, D. \& Sochalski, J., 2005, 'Nursing shortage and International nurse migration', The International of Nurses Review 52, 253-262.

Starbuck, G.H., 2002, Families in Context, Wardsworth Thompson Learning, Singapore.

Stockdale, A., 2007, 'Out-Migration from Rural Scotland: The Importance of Family and Social Networks', Blackwell Publishers 42(1), pp 1-24.

Struebert, J.H. \& Carpenter, D.R., 1999, Qualitative Research in Nursing: Advancing the Humanistic Interpretive, Lippincott Company, Philadelphia.

The World Health Organisation Report, 2006, Managing the exits from the Workforce, viewed, 06 March 2007, from http://www.who.int/whr/2006/06_chap5_en.pdf

Thupayagale-Thsewneagae, G, 2007, 'Migration of nurses: Is there any option?' International Nursing Review 54, 107-109.

Troy, P.H., Wyness, L. \& McAuliffe, E., 2007, 'Nurses' experience of recruitment and migration from developing countries: a phenomenological approach', Human Resources for Health 5 (1), 5-15, from http://www. human-resources-health.com/ content/5/1/15 